\title{
EFFECTS OF PROTON PUMP INHIBITORS ON GASTRIC VOLUME AND GASTRIC PH IN ADULT PATIENTS POSTED FOR ELECTIVE OPERATIVE PROCEDURES
}

\author{
Shaikh Mukhtar Nazir Ahmed"1, Yogesh Wamanrao Patil2, Satish Gopalrao Deshpande³, G. L. Anmod4 \\ ${ }^{1}$ Specialty Medical Officer, Department of Anaesthesiology, Government Medical College, Latur. \\ ${ }^{2}$ Specialty Medical Officer, Department of Anaesthesiology, Government Medical College, Latur. \\ 3 Professor, Department of Anaesthesiology, Government Medical College, Latur. \\ 4 Professor, Department of Surgery, Government Medical College, Latur.
}

\begin{abstract}
Under general anaesthesia even in elective operative procedure, there are chances of aspiration of gastric contents resulting in acid aspiration syndrome. $\mathrm{H}_{2}$ antagonists Ranitidine and Proton Pump Inhibitors were evaluated to compare efficacy of the drugs in decreasing gastric volume and increasing gastric $\mathrm{pH}$ when administered orally overnight and early in the morning; 250 patients of ASA grade I and II of either sex were divided in 5 equal Groups of 50 patients each. Group I patients received Tab. Placebo, Group II received Tab. Ranitidine $150 \mathrm{mg}$, Group III received Tab. Omeprazole $20 \mathrm{mg}$, Group IV received Tab. Pantoprazole $40 \mathrm{mg}$ and Group V patients received Tab. Esomeprazole $40 \mathrm{mg}$ overnight at $10 \mathrm{pm}$ and $6 \mathrm{am}$ morning. Prior to induction of anaesthesia, gastric contents were aspirated after insertion of nasogastric tube (Ryles tube) with the help of syringe. The volume and $\mathrm{pH}$ of aspirated gastric contents was measured in all patients. It was observed that in proton pump inhibitors Groups (III, IV and V) and also in Group II (Ranitidine), the gastric volume was significantly less as compared to control Group I. Mean gastric volume in Group II was $13.38 \pm 3.3 \mathrm{~mL}$, in Group III $10.7 \pm 3.6 \mathrm{~mL}$, in Group IV 10.4 $\pm 3.4 \mathrm{~mL}$ and in Group V 9.58 $\pm 3.2 \mathrm{~mL}$. There was no significant difference in gastric volume amongst Groups III, IV and V. There was significant difference in proton pump inhibitors Group and ranitidine Group as far as gastric volume was concerned. Mean gastric pH was 5.31 \pm 0.48 in Group II, $4.83 \pm 0.35$ in Group III, $4.82 \pm 0.39$ in Group IV and 5.17 \pm 0.44 in Group V. There was no significant difference in gastric pH in Group II, III, IV and V. Gastric pH and gastric volume were significantly above and below critical values in study Groups as compared to control Group. It is concluded that proton pump inhibitors, Omeprazole, Pantoprazole and Esomeprazole can be administered orally overnight and early morning to increase gastric $\mathrm{pH}$ and decrease gastric volume in patients posted for elective operative procedures under general anaesthesia. Proton pump inhibitors satisfactorily increases gastric $\mathrm{pH}$ and reduces gastric volume much above critical values. Esomeprazole was found to be superior to Omeprazole and Pantoprazole in this regards.
\end{abstract}

\section{KEYWORDS}

Critical Gastric Volume Critical pH, Acid Aspiration Syndrome, $\mathrm{H}_{2}$ Antagonist, Proton Pump Inhibitors.

HOW TO CITE THIS ARTICLE: Ahmed SMN, Patil YW, Deshpande SG, et al. Effects of proton pump inhibitors on gastric volume and gastric PH in adult patients posted for elective operative procedures. J. Evolution Med. Dent. Sci. 2016;5(62):4346-4350, DOI: $10.14260 /$ jemds/2016/992

\section{INTRODUCTION}

Aspiration of gastric contents into respiratory tract during induction of general anaesthesia and endotracheal intubation has been recognized as a serious complication and may be one of the important cause of death. James Simpson. ${ }^{1}$ in 1953, reported first anaesthesia death due to this complication and also by (Hamelberge and Bosomworth et al 1964.2 Bannister and Sattirao 1962.3 Mendelson (1946). 4 reported 66 deaths during inhalation of nitrous oxide, oxygen and ether in obstetric patients and described as syndrome with wheeze, signs of hypoxia and pulmonary oedema.

This is mainly a problem in obstetric patients in labour where due to altered physiology there is delay in emptying time of stomach. There is possibility of vomiting of stomach contents and possibility of regurgitation and aspiration. The oxyntic cells of stomach secretes, hydrochloric acid with $\mathrm{pH}$ 0.87 and concentration about $140 \mathrm{mmol} / \mathrm{lit}$ secondary to stimulation due to food particles (Solid and semisolid) in the

Financial or Other, Competing Interest: None.

Submission 24-06-2016, Peer Review 21-07-2016,

Acceptance 27-07-2016, Published 03-08-2016.

Corresponding Author:

Dr. Shaikh Mukhtar Nazir Ahmed

Department of Anaesthesiology

Government Medical College,

Old Civil Hospital Campus,

Latur-413512, Maharashtra.

E-mail: onlinemukhtar@gmail.com

DOI: $10.14260 /$ jemds/2016/992 stomach. The critical $\mathrm{pH}$ of gastric contents responsible for pulmonary damage is 2.5 and critical volume $25 \mathrm{~mL}$ in adult patients $(0.4 \mathrm{~mL} / \mathrm{kg})$.

This problem of aspiration of gastric contents can be minimized by preventing the contents reaching to respiratory tract and rendering the gastric contents less harmful by using various methods.

It is universally accepted that $\mathrm{H}_{2}$ receptor antagonist are used to reduce the gastric acidity or increase alkalinity. Recently introduced Proton Pump Inhibitors (Omeprazole, Pantoprazole, newer agents Esomeprazole and Rabeprazole) can be tried to decrease gastric volume and increase gastric $\mathrm{pH}$. The present study was undertaken to compare and evaluate efficacy of oral Ranitidine and proton pump inhibitors (Omeprazole, Pantoprazole, Esomeprazole) when given preoperatively in adult patients undergoing elective operative procedures.

\section{MATERIAL AND METHODS}

After approval of Ethical Committee of Medical College, present study was undertaken; 250 patients of either sex between age range of 15-60 years of ASA grade I and II posted for elective operative procedures were studied. These patients were divided into 5 equal groups of 50 patients according to the oral study drugs administered.

From every patient, written valid consent was obtained for anaesthesia and operative procedure and valid consent for insertion of Ryles tube was taken. 
Group I: Received Tab. Placebo.

Group II: Received Tab. Ranitidine $150 \mathrm{mg}$.

Group III: Received Tab. Omeprazole $20 \mathrm{mg}$.

Group IV: Received Tab. Pantoprazole $40 \mathrm{mg}$.

Group V: Received Tab. Esomeprazole $40 \mathrm{mg}$.

The patients with known acid peptic disease, gastrooesophageal efflux, patients on medication like - NSAID, $\mathrm{H}_{2}$ receptors antagonists or proton pump inhibitors were excluded from the study. All patients were administered the drugs according to Group allotments at 10 pm overnight and 6 am in the morning with sip of water.

On the day of surgery before administration of any premedication, 16-French G Ryles tube was introduced nasally into the stomach. Gastric fluid was aspirated with 20 $\mathrm{mL}$ syringe in different positions in order to aspirate the contents maximally to ensure gastric emptying. The volume of gastric content aspirated was measured and $\mathrm{pH}$ of gastric fluid was determined with $\mathrm{pH}$ meter.

Then all patients were pre-medicated with Inj. Midazolam $0.3 \mathrm{mg} / \mathrm{kg}$, Inj. Pentazocine $0.5 \mathrm{mg} / \mathrm{kg}$. Anaesthesia was induced with Inj. Thiopentone, Inj. Suxamethonium $1 \mathrm{mg} / \mathrm{kg}$ and endotracheal intubation. Anaesthesia was maintained on Gas + Oxygen intermittent doses of Inj. Rocuronium $1 \mathrm{mg} / \mathrm{kg}$ on controlled ventilation. Intraoperatively, all patients were monitored for vital parameters and at the end of surgery reversal was carried out with Inj. Neostigmine and Inj. Atropine. After complete reversal, all patients were extubated and shifted to recovery room and respective wards.

\section{OBSERVATIONS}

250 patients were divided into 5 equal Groups of 50 patients, each according to study drugs administered orally.

\section{The Age Distribution was as shown in Table I}

There were maximum number of patients about $80 \%$ in age range of 21-30, 31-40 and 41-50 years in all Groups. Mean age range was $37.02 \pm 11.50$ years in Group I, $37.52 \pm 11.21$ in Group II, 36.94 \pm 11.16 in Group III, $37.88 \pm 11.43$ in Group IV and $38.14 \pm 11.48$ years in Group V. There was no significant difference in age range in all Groups.

\section{Sex Wise Distribution was as shown in Table II}

There was almost identical sex distribution in all five Groups. There was not much difference in sex distribution.

\section{Weight Wise Distribution was as shown in Table III}

Maximum number of patients were in weight range of 51-55, 56-60 and 61-65 kg in all Groups. Mean weight in Group I patients was $59.22 \pm 5.68 \mathrm{~kg}, 58.92 \pm 5.72$ in Group II, $59.00 \pm 5.96$ in Group III, 58.44 \pm 6.08 in Group IV and $58.76 \pm 5.80 \mathrm{~kg}$ in Group $\mathrm{V}$ patients. There was no significant difference in weight range in any Group.

In all Patient's Height was Measured in cms and Distribution was as shown in Table IV

The maximum number of patients were having height range in between $151-155 \mathrm{~cm}, 156-160 \mathrm{~cm}$ and $161-165 \mathrm{~cm}$ in all Groups.
Mean height in Group I patients was $158.78 \pm 5.90 \mathrm{~cm}$, $157.80 \pm 6.0 \mathrm{~cm}$ in Group II, $158.70 \pm 5.55 \mathrm{~cm}$ in Group III, $159.0 \pm 6.12 \mathrm{~cm}$ in Group IV and $158.64 \pm 5.93 \mathrm{~cm}$ in Group V patients. There was no significant difference in height range was concerned in all Groups.

All Patients were Evaluated Pre-anaesthesia for Fitness of Anaesthesia and were Graded as shown in Table No. V Almost all patients were in ASA grade I to II in all 5 Groups. There was no difference in any Group.

After Ryles tube aspiration, the gastric volume was measured in all patients before induction of anaesthesia. The gastric content aspirated were noted as shown in Table No. VI.

Mean gastric volume in Group I patients was 25.6 \pm 3.99 $\mathrm{mL}$ in Group I, $13.38 \pm 3.66 \mathrm{~mL}$ in Group II, $10.77 \pm 3.6 \mathrm{~mL}$ in Group III, $10.48 \pm 3.47 \mathrm{~mL}$ in Group IV and $9.58 \pm 3.27 \mathrm{~mL}$ in Group V patients. Mean gastric volume was highly significantly more in Group I (Placebo Group) as compared to any other Group. There was no significant difference in mean gastric volume amongst Groups III, IV and V. In Group $\mathrm{V}$, mean gastric volume was insignificantly less as compared to Groups III and IV. It was observed that preoperative medication with proton pump inhibitors (Omeprazole, Pantoprazole and Esomeprazole) significantly decreases gastric volume similar to Group II (Ranitidine) as compared to control Group.

In Group I, maximum number of patients (84\%) had gastric volume in the range of 21-30 mL. In Group II, $80 \%$ of patients had gastric volume in the range of $11-25 \mathrm{~mL}$. In Groups III, IV and V there were maximum number of patients who had gastric volume less than $20 \mathrm{~mL}$, i.e. below critical volume limit of $25 \mathrm{~mL}$.

Pre-operatively, Gastric Aspirate was Subjected to Estimation pH with Portable pH Meter and the Readings of Gastric pH in all Groups was noted as shown in Table VII

Mean gastric $\mathrm{pH}$ was $3.04 \pm 0.4$ in Group I patients, $5.31 \pm 0.48$ in Group II, $4.83 \pm 0.35$ in Group III, $4.82 \pm 0.35$ in Group IV and $5.17 \pm 0.44$ in Group $\mathrm{V}$ patients. Gastric $\mathrm{pH}$ was significantly acidic in control Group (Placebo) in all patients of Group I. Gastric pH was significantly more alkaline in Group II patients followed by Groups V, IV and III. In Groups II and $\mathrm{V}$, gastric $\mathrm{pH}$ was insignificantly more as compared to Groups III and IV. Overall, gastric $\mathrm{pH}$ was above critical $\mathrm{pH}$ i.e. 2.5 in patients of proton pump inhibitors and $\mathrm{H}_{2}$ receptor antagonist.

In Group I, more than $76 \%$ of patients had gastric $\mathrm{pH}$ above critical pH 2.5 in the range of 2.1 to 3.5. In Group II, $92 \%$ of patients had gastric $\mathrm{pH}$ in range of 4.6-6.0. In Group III and IV, 96\% of patients had gastric $\mathrm{pH}$ in the range of 4.15.5. In Group V, 88\% of patients had gastric $\mathrm{pH}$ in the range of 4.6-6.0. Thus, in all study Group patients $80-90 \%$ of patients had gastric $\mathrm{pH}$ in the range of 4.6-6.0, i.e. much higher than critical $\mathrm{pH} 2.5$.

It was observed that $80-90 \%$ of patients in Group II (Ranitidine) and Groups III, IV and V (Proton pump inhibitors - Omeprazole, Pantoprazole and Esomeprazole) had gastric volume less than $25 \mathrm{~mL}$ and gastric $\mathrm{pH}$ more than 2.5 , i.e. above critical values. 


\begin{tabular}{|c|c|c|c|c|c|c|c|c|c|c|}
\hline \multirow{2}{*}{$\begin{array}{l}\text { Age in } \\
\text { Years }\end{array}$} & \multicolumn{2}{|c|}{ Group I } & \multicolumn{2}{|c|}{ Group II } & \multicolumn{2}{|c|}{ Group III } & \multicolumn{2}{|c|}{ Group IV } & \multicolumn{2}{|c|}{ Group V } \\
\hline & No. & $\%$ & No. & $\%$ & No. & $\%$ & No. & $\%$ & No. & $\%$ \\
\hline $15-20$ & 3 & 6 & 2 & 4 & 3 & 6 & 3 & 6 & 2 & 4 \\
\hline $21-30$ & 13 & 26 & 14 & 28 & 14 & 28 & 12 & 24 & 14 & 28 \\
\hline $31-40$ & 15 & 30 & 13 & 26 & 14 & 28 & 15 & 30 & 13 & 26 \\
\hline 41-50 & 12 & 24 & 13 & 26 & 12 & 24 & 13 & 26 & 13 & 26 \\
\hline $51-60$ & 7 & 14 & 8 & 16 & 7 & 14 & 7 & 14 & 8 & 16 \\
\hline Total & 50 & & 50 & & 50 & & 50 & & 50 & \\
\hline Mean & \multicolumn{2}{|c|}{$37.02 \pm 11.56$} & \multicolumn{2}{|c|}{$37.82 \pm 11.21$} & \multicolumn{2}{|c|}{$36.94 \pm 11.16$} & \multicolumn{2}{|c|}{$37.88 \pm 11.43$} & \multicolumn{2}{|c|}{$38.14 \pm 11.48$} \\
\hline
\end{tabular}

\begin{tabular}{|c|c|c|c|c|c|c|c|c|c|c|}
\hline \multirow{2}{*}{ Gender } & \multicolumn{2}{|c|}{ Group I } & \multicolumn{2}{|c|}{ Group II } & \multicolumn{2}{|c|}{ Group III } & \multicolumn{2}{|c|}{ Group IV } & \multicolumn{2}{|c|}{ Group V } \\
\hline & No. & $\%$ & No. & $\%$ & No. & $\%$ & No. & $\%$ & No. & $\%$ \\
\hline Male & 30 & 60 & 28 & 56 & 31 & 62 & 32 & 64 & 28 & 56 \\
\hline Female & 20 & 40 & 22 & 44 & 19 & 38 & 18 & 36 & 22 & 44 \\
\hline Total & 50 & & 50 & & 50 & & 50 & & 50 & \\
\hline
\end{tabular}

\begin{tabular}{|c|c|c|c|c|c|c|c|c|c|c|}
\hline \multirow{2}{*}{ Weight Range in Kg } & \multicolumn{2}{|c|}{ Group I } & \multicolumn{2}{|c|}{ Group II } & \multicolumn{2}{|c|}{ Group III } & \multicolumn{2}{|c|}{ Group IV } & \multicolumn{2}{|c|}{ Group V } \\
\hline & No. & $\%$ & No. & $\%$ & No. & $\%$ & No. & $\%$ & No. & $\%$ \\
\hline $45-50$ & 2 & 4 & 3 & 6 & 3 & 6 & 2 & 4 & 2 & 4 \\
\hline $51-55$ & 14 & 28 & 12 & 24 & 13 & 26 & 14 & 28 & 13 & 26 \\
\hline $56-60$ & 14 & 28 & 15 & 30 & 15 & 30 & 14 & 28 & 15 & 30 \\
\hline $61-65$ & 12 & 24 & 13 & 26 & 12 & 24 & 12 & 24 & 13 & 26 \\
\hline $66-70$ & 8 & 16 & 7 & 14 & 7 & 14 & 8 & 16 & 7 & 14 \\
\hline Total & 50 & & 50 & & 50 & & 50 & & 50 & \\
\hline Mean & \multicolumn{2}{|c|}{$59.22 \pm 5.68$} & \multicolumn{2}{|c|}{$58.92 \pm 5.72$} & \multicolumn{2}{|c|}{$59.00 \pm 5.96$} & \multicolumn{2}{|c|}{$58.44 \pm 6.08$} & \multicolumn{2}{|c|}{$58.76 \pm 5.80$} \\
\hline & & able & lowi & eigh & e Dist & tion & & & & \\
\hline
\end{tabular}

\begin{tabular}{|c|c|c|c|c|c|c|c|c|c|c|}
\hline \multirow{2}{*}{ Height in Cms } & \multicolumn{2}{|c|}{ Group I } & \multicolumn{2}{|c|}{ Group II } & \multicolumn{2}{|c|}{ Group III } & \multicolumn{2}{|c|}{ Group IV } & \multicolumn{2}{|c|}{ Group V } \\
\hline & No. & $\%$ & No. & $\%$ & No. & $\%$ & No. & $\%$ & No. & $\%$ \\
\hline $145-150$ & 3 & 6 & 4 & 8 & 2 & 4 & 3 & 6 & 3 & 6 \\
\hline $151-155$ & 13 & 26 & 14 & 28 & 13 & 26 & 13 & 26 & 13 & 26 \\
\hline $156-160$ & 15 & 30 & 14 & 28 & 15 & 30 & 14 & 28 & 15 & 30 \\
\hline 161-165 & 12 & 24 & 12 & 24 & 13 & 26 & 13 & 26 & 12 & 24 \\
\hline $166-170$ & 7 & 14 & 6 & 12 & 7 & 14 & 7 & 14 & 7 & 14 \\
\hline Total & 50 & & 50 & & 50 & & 50 & & 50 & \\
\hline Mean & \multicolumn{2}{|c|}{$37.02 \pm 11.56$} & \multicolumn{2}{|c|}{$37.82 \pm 11.21$} & \multicolumn{2}{|c|}{$36.94 \pm 11.16$} & \multicolumn{2}{|c|}{$37.88 \pm 11.43$} & \multicolumn{2}{|c|}{$38.14 \pm 11.48$} \\
\hline & & & le I & & Wis & 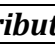 & & & & \\
\hline
\end{tabular}

\begin{tabular}{|c|c|c|c|c|c|c|c|c|c|c|}
\hline \multirow{2}{*}{ ASA Grade } & \multicolumn{2}{|c|}{ Group I } & \multicolumn{2}{|c|}{ Group II } & \multicolumn{2}{|c|}{ Group III } & \multicolumn{2}{|c|}{ Group IV } & \multicolumn{2}{|c|}{ Group V } \\
\hline & No. & $\%$ & No. & $\%$ & No. & $\%$ & No. & $\%$ & No. & $\%$ \\
\hline I & 29 & 58 & 30 & 60 & 31 & 62 & 32 & 64 & 30 & 60 \\
\hline II & 21 & 42 & 20 & 40 & 19 & 38 & 18 & 36 & 20 & 40 \\
\hline Total & 50 & & 50 & & 50 & & 50 & & 50 & \\
\hline & & & le V: & ng & ade 1 & utiol & & & & \\
\hline
\end{tabular}

\begin{tabular}{|c|c|c|c|c|c|c|c|c|c|c|}
\hline \multirow{2}{*}{ Gastric Volume in mL } & \multicolumn{2}{|c|}{ Group I } & \multicolumn{2}{|c|}{ Group II } & \multicolumn{2}{|c|}{ Group III } & \multicolumn{2}{|c|}{ Group IV } & \multicolumn{2}{|c|}{ Group V } \\
\hline & No. & $\%$ & No. & $\%$ & No. & $\%$ & No. & $\%$ & No. & $\%$ \\
\hline $5-10$ & 0 & 0 & 10 & 20 & 30 & 60 & 32 & 64 & 35 & 70 \\
\hline $11-15$ & 0 & 0 & 30 & 60 & 11 & 22 & 10 & 20 & 10 & 20 \\
\hline $16-20$ & 8 & 16 & 8 & 16 & 9 & 18 & 8 & 16 & 5 & 10 \\
\hline $21-25$ & 10 & 20 & 2 & 4 & 0 & 0 & 0 & 0 & 0 & 0 \\
\hline $26-30$ & 29 & 58 & 0 & 0 & 0 & 0 & 0 & 0 & 0 & 0 \\
\hline $31-35$ & 3 & 6 & 0 & 0 & 0 & 0 & 0 & 0 & 0 & 0 \\
\hline Total & \multicolumn{2}{|c|}{50} & \multicolumn{2}{|c|}{50} & \multicolumn{2}{|c|}{50} & \multicolumn{2}{|c|}{50} & \multicolumn{2}{|c|}{50} \\
\hline Mean & \multicolumn{2}{|c|}{$25.6 \pm 3.99$} & \multicolumn{2}{|c|}{$13.38 \pm 3.66$} & \multicolumn{2}{|c|}{$10.70 \pm 3.64$} & \multicolumn{2}{|c|}{$10.48 \pm 3.47$} & \multicolumn{2}{|c|}{$9.58 \pm 3.27$} \\
\hline & & 4 & ving & 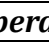 & astri & ume & & & & \\
\hline
\end{tabular}




\begin{tabular}{|c|c|c|c|c|c|c|c|c|c|c|}
\hline \multirow{2}{*}{ Gastric pH } & \multicolumn{2}{|c|}{ Group I } & \multicolumn{2}{|c|}{ Group II } & \multicolumn{2}{|c|}{ Group III } & \multicolumn{2}{|c|}{ Group IV } & \multicolumn{2}{|c|}{ Group V } \\
\hline & No. & $\%$ & No. & $\%$ & No. & $\%$ & No. & $\%$ & No. & $\%$ \\
\hline $1.5-2.0$ & 2 & 4 & 0 & 0 & 0 & 0 & 0 & 0 & 0 & 0 \\
\hline $2.1-2.5$ & 6 & 12 & 0 & 0 & 0 & 0 & 0 & 0 & 0 & 0 \\
\hline $2.6-3.0$ & 12 & 24 & 0 & 0 & 0 & 0 & 0 & 0 & 0 & 0 \\
\hline $3.1-3.5$ & 26 & 52 & 0 & 0 & 0 & 0 & 0 & 0 & 0 & 0 \\
\hline $3.6-4.0$ & 3 & 6 & 0 & 0 & 0 & 0 & 2 & 4 & 1 & 2 \\
\hline $4.1-4.5$ & 1 & 2 & 2 & 4 & 9 & 18 & 12 & 24 & 3 & 6 \\
\hline $4.6-5.0$ & 0 & 0 & 12 & 24 & 26 & 52 & 24 & 48 & 14 & 28 \\
\hline $5.1-5.5$ & 0 & 0 & 24 & 48 & 13 & 26 & 10 & 20 & 20 & 40 \\
\hline $5.6-6.0$ & 0 & 0 & 10 & 20 & 2 & 4 & 2 & 4 & 10 & 20 \\
\hline $6.1-6.5$ & 0 & 0 & 2 & 4 & 0 & 0 & 0 & 0 & 2 & 4 \\
\hline Total & \multicolumn{2}{|c|}{50} & \multicolumn{2}{|c|}{50} & \multicolumn{2}{|c|}{50} & \multicolumn{2}{|c|}{50} & \multicolumn{2}{|c|}{50} \\
\hline Mean pH & \multicolumn{2}{|c|}{$3.04 \pm 0.4$} & \multicolumn{2}{|c|}{$5.31 \pm 0.48$} & \multicolumn{2}{|c|}{$4.83 \pm 0.35$} & \multicolumn{2}{|c|}{$4.82 \pm 0.39$} & \multicolumn{2}{|c|}{$5.17 \pm 0.44$} \\
\hline & & & able & owi & era & ast & & & & \\
\hline
\end{tabular}

\section{DISCUSSION}

Perioperative morbidity and mortality secondary to aspiration of gastric contents is avoidable complication during induction of general anaesthesia reported by Meril and Hingson et al 1951). 5 , 33\% by Hall et al (1940). $610-34 \%$ by Hamelberg et al (1964). ${ }^{2}$ Lunn and Mushin et al (1982). ${ }^{7}$ found pulmonary aspiration of gastric contents to be leading cause of death directly related to general anaesthesia.

In 1946, Mandelson. ${ }^{4}$ an American Cardiologist reported that obstetric patients who inhaled gastric contents during administration of nitrous oxide, oxygen and ether anaesthesia developed signs of pulmonary oedema. He described the symptoms of acute pulmonary oedema as bronchospasm, hypoxia and secretions. The basis of aspiration was the presence of liquid and semisolid material in the stomach, triggered the emesis and loss of protective reflexes under general anaesthesia disabled the aspirate to travel into respiratory tract.

Borson and Adriani et al (1954). ${ }^{8}$, Hall et al (1950).6, Mendelson et al (1948).4, Teabeaut et al (1952). ${ }^{9}$ Roberts and Shirley et al (1974). ${ }^{10}$ and Davidson et al (1970).11 and many others have worked on gastric volume, gastric $\mathrm{pH}$ under general anaesthesia and also on critical volume and critical $\mathrm{pH}$ for occurrence of acid aspiration syndrome. They also worked on measures to prevent aspiration of gastric contents into respiratory tract.

Davidson et al (1970). ${ }^{11}$ stated that the gastric emptying time is prolonged by $50 \%$ from 34 weeks of pregnancy onwards. The contributing factors are pain, anxiety, administration of narcotics and belladonna alkaloids. Crawford et al (1970).12 and Virginia Bond et al (1979).13 quoted that critical pH 2.5 is responsible for the symptoms of acid aspiration syndrome, but gastric $\mathrm{pH}$ more than $2.5 \mathrm{up}$ to 3.5 may also cause some symptoms of aspiration.

Alkaline mixture of magnesium trisilicate were tried to increase gastric $\mathrm{pH}$, but due to increased gastric volume may not avoid aspiration of gastric contents (Keith Maliniak et al (1979). ${ }^{14}$ Schwartz et al (1980). ${ }^{15}$ have shown that antacid aspiration to be more harmful than acid aspiration. $\mathrm{H}_{2}$ receptors present in the stomach are responsible for gastric acid secretion in response to histamine stimulation. $\mathrm{H}_{2}$ receptor antagonist Cimetidine, Ranitidine, Famotidine counter act release of gastric acid, thereby increases gastric $\mathrm{pH}$.
J Moore et al (1989).16 observed that proton pump inhibitor Omeprazole increases gastric $\mathrm{pH}$ and reduces gastric volume.

In the present study, proton pump inhibitors Omeprazole, Pantoprazole and Esomeprazole were compared with Ranitidine to evaluate efficacy to increase gastric $\mathrm{pH}$ and decrease gastric volume when orally administered in elective patients posted for operative procedures. Our demographic data coincides with other authors (F Escolano et al 1992.17 D. Menis et al 2003.18 A Hussein et al 2008.19 and S Sadawarte et al 2009.20).

Prior to induction of anaesthesia, gastric contents were aspirated with syringe and measured. Mean volume of gastric aspirate was Group I (Control) $25.6 \mathrm{~mL}$, Group II 13.3 mL, Group III 10.7 mL, Group IV $10.4 \mathrm{~mL}$ and in Group V 9.5 $\mathrm{mL}$. The mean gastric volume was significantly less in proton pump inhibitors Groups III, IV and V as compared to Group I. In Group II, mean gastric volume was highly significantly least as compared to control Group and insignificantly more than III, IV and V Groups. Gastric volume was lowest in Esomeprazole Group. Our observations coincides with $\mathrm{F}$ Escolano et al (1992). ${ }^{17}$, D. Menis et al (2003). ${ }^{18}$ A Hussein et al (2008). ${ }^{19}$ and S Sadawarte et al (2009). ${ }^{20}$

In the present study, gastric $\mathrm{pH}$ was estimated with portable $\mathrm{pH}$ meter after aspiration of gastric contents. Mean gastric $\mathrm{pH}$ in Group I was 3.0, in Group II 5.3, in Group III 4.8, in Group IV 4.8 and in Group V was 5.1. It was observed that gastric $\mathrm{pH}$ was significantly more in all study Groups as compared to control Group. In Group II, gastric pH was significantly more as compared to proton pump inhibitors.

There was no significant difference in gastric $\mathrm{pH}$ among proton pump inhibitors, but $\mathrm{pH}$ was significantly more than control Group. Esomeprazole was found to be more efficient (Equivalent to Ranitidine) than Omeprazole and Pantoprazole as far as increase in gastric $\mathrm{pH}$ was concerned. Our observations were similar with those of Davil Morison et al (1982). ${ }^{21} \mathrm{~T}$ Gin et al (1999). ${ }^{22}$ Escolano et al (1992). ${ }^{17}$, Anand Sagar et al (1996).23, K. Nishina et al (1999). ${ }^{24}$ A Hussein et al (2008).19 all have observed proton pump inhibitors significantly increases gastric $\mathrm{pH}$ as compared to control Group. 


\section{CONCLUSIONS}

All the time there are every chance of aspiration of gastric contents at the time of induction of anaesthesia and endotracheal intubation even in elective operative procedures. $\mathrm{H}_{2}$ receptor antagonist Ranitidine is known to increase gastric $\mathrm{pH}$ and reduce gastric volume below critical values. Proton pump inhibitors when administered orally (overnight and early in morning) significantly increases gastric $\mathrm{pH}$ and decreases gastric volume. So proton pump inhibitors Omeprazole, Pantoprazole and Esomeprazole can be tried to avoid chances of acid aspiration syndrome under general anaesthesia even in elective operative procedures. Esomeprazole was found to be superior to Pantoprazole and Omeprazole in this regard.

\section{REFERENCES}

1. James S. Remarks on the alleged case of death from the action of chloroform. Lancet 1848;51(1276):175-6.

2. Hamelberg W, Bosomworth P. Aspiration pneumonitis experimental studies and clinical observations. Anaesth and Analg 1964;43:669-77.

3. Bannister WK, Sattilrao AJ. Vomiting and aspiration during anaesthesia. Anaesthesiology 1962;23:251-64.

4. Mendelson CL. Aspiration of stomach contents into lungs during obstetric anaesthesia. Amm J Obst \& Gynec 1946;52:191-205.

5. Merill RB, Hingson RA. Studies of incidence of maternal mortality from aspiration of vomitus during anaesthesia occurring in major obstetric hospitals in the U.S. Anaesth and Analg 1951;30(3):121-35.

6. Hall CC. Aspiration pneumonitis as an obstetric hazard. JAMA 1940;114(9):728-33.

7. Lunn JN, Mushin WM. Mortality associated with anaesthesia. Anaesthesia 1982;37(8):856.

8. Bersone W, Adriani J. Silent regurgitation and aspiration of gastric contents during anaesthesia. Anaesthesiology 1954;15(6):644-9.

9. Teabeaut JR. Aspiration of gastric contents: an experimental study. Amer J Pathol 1952;28(1):51-67.

10. Roberts RB, Shirley MA. Reducing the risk of acid aspiration during caesarean section. Anaesth and Analg 1974;53(6):859-68.

11. Davidson JS, Davison MC, Hay DM. Gastric emptying time in pregnancy and labour. Jr Obstet Gynec Br Commonw 1970;77:37-41.
12. Crowford JS. The anaesthetist contribution to maternal mortality. British Jr of Anaesthesia 1970;42(1):70-3.

13. Bond VK, Stoelting RK, Gupta CD. Pulmonary aspiration syndrome after inhalation of gastric fluid containing antacids. Anaesthesiology 1979;51(5):452-3.

14. Maliniak K, Vakil AH. Preanaesthetic cimetidine and gastric $\mathrm{pH}$. Anaesth and Analg 1979;58(4):309-13.

15. Shwartz DJ, Wynne J, Gibbs CP, et al. The pulmonary consequences of aspiration of gastric contents of $\mathrm{pH}$ value greater than 2.5. Amm Rev Respiratory Dis 1980;121(1):119-26.

16. Moore J, Flynn RJ, Sampaio M, et al. Effect of single dose omeprazole on intragastric acidity and volume during obstetric anaesthesia. Anaesthesia 1989;44(7):559-62.

17. Escolano F, Castano J, Lopez R, et al. Effect of omeprazole, ranitidine, famotidine and placebo on gastric secretion in patients undergoing elective surgery. British $\mathrm{Jr}$ of Anaesth 1992;69:404-6.

18. Memis D, Alparslan T, Beyhan K, et al. The effect of intravenous pantoprazole and ranitidine for improving preoperative gastric fluid properties in adults undergoing elective surgery. Anaesth and Analg 2003;97(5):1360-3.

19. Hussein A, Al-Saeed AH, Habib SS. Esomeprazole as prophylactic agent for acid aspiration syndrome in adult patients undergoing elective surgery: a triple blind placebo controlled clinical trial. SAJAA 2008;14(5):3942.

20. Sadawarte S, Vaidyanathan P, Sareen R. The efficacy of single dose intravenous esomeprazole and pantoprazole on gastric $\mathrm{pH}$ and volume: a double blind study. Jr of Anaesth And Clinical Pharm 2009;25(2):217-20.

21. Morrison DH, Dunn GL, Fargas-Babjak AM, et al. A double blind comparison of cimetidine and ranitidine as prophylaxis against gastric aspiration syndrome. Anaesth Analg 1982;61(12):988-92.

22. Gin T, Ewart MC, Yau G, et al. Effect of oral omeprazole on intragastric $\mathrm{pH}$ and volume in women elective caesarean section. British Jr of Anaesth 1990;65(5):616-9.

23. Sagar A, Shetty RN, Koregaonkar SV. Comparative evaluation of cimetidine, ranitidine and famotidine for acid aspiration prophylaxis. Indian $\mathrm{Jr}$ of Anaesth 1996;44(3):177-80.

24. Nashina K, Mikawa K, Takao Y, et al. A comparison of rabeprazole, lansoprazole and ranitidine for improving preoperative gastric fluid property in adults undergoing elective surgery. Anaesth and Analg 2000;90(3):717-21. 